Neurosurg Focus 23 (4):E12, 2007

\title{
Targeted drug therapy for meningiomas
}

\author{
Andrew D. Norden, M.D., Jan Drappatz, M.D., and Patrick Y. Wen, M.D. \\ Division of Neuro-Oncology, Department of Neurology, Brigham and Women's Hospital; and Center \\ for Neuro-Oncology, Dana-Farber-Brigham and Women's Cancer Center, Boston, Massachusetts
}

\begin{abstract}
$\checkmark$ Although advances in surgery, radiation therapy, and stereotactic radiosurgery have significantly improved the treatment of meningiomas, there remains an important subset of patients whose tumors are refractory to conventional therapy. Treatment with traditional chemotherapeutic agents has provided minimal benefit. In this review, the role of targeted molecular therapies for recurrent or progressive meningiomas is discussed. (DOI: $10.3171 / \mathrm{FOC}-07 / 10 / E 12)$
\end{abstract}

\section{KEY WORDS • kinase inhibition • meningioma • targeted drug therapy}

$\mathrm{M}$ ENINGIOMAS are primary central nervous system tumors composed of neoplastic meningothelial (arachnoid cap) cells. ${ }^{68}$ They represent the most common type of benign intracranial tumor. With an annual incidence of approximately 2.3 to 6 per 100,000 persons, meningiomas account for approximately 13 to $26 \%$ of primary brain tumors in adults. ${ }^{726,74,135}$ Many meningiomas are asymptomatic in life and are found incidentally in $1.4 \%$ of autopsies. ${ }^{74}$ They occur twice as often in women as in men, and the mean age of patients at diagnosis is approximately 58 years. ${ }^{7,26}$ Ninety percent of meningiomas are intracranial, and of these $90 \%$ are supratentorial. Meningioma risk factors that account for a relatively small number of cases include NF2 and cranial irradiation. $26,74,105,135$

The WHO classifies this tumor into three main categories: benign (WHO Grade I), atypical (WHO Grade II), and malignant (anaplastic) (WHO Grade III), based on the degree of anaplasia, number of mitoses, and presence of

Abbreviations used in this paper: $\mathrm{AED}=$ antiepileptic drug; $\mathrm{CDK}=$ cyclin-dependent kinase; $\mathrm{CML}=$ chronic myelocytic leukemia; $\mathrm{EGF}=$ epidermal growth factor; EGFR = EGF receptor; $\mathrm{ET}=$ endothelin; $\mathrm{GF}$ = transforming growth factor; $\mathrm{GH}$ = growth hormone; $\mathrm{GHR}=\mathrm{GH}$ receptor; $\mathrm{HGF} / \mathrm{SF}=$ hepatocyte growth factor/scatter factor; HSP90 = heat shock protein 90; IAP = inhibitors of apoptosis proteins; IGF = insulin-like growth factor; IGFBP = IGF binding protein; IGFR = IGF receptor; MAPK = mitogen-activated protein kinase; MEK = MAPK kinase; mTOR = mammalian target of rapamycin; NABTC $=$ North American Brain Tumor Consortium; NF2 = neurofibromatosis type 2 ; PDGF $=$ platelet-derived growth factor; $\mathrm{PDGFR}=$ PDGF receptor; $\mathrm{PI} 3 \mathrm{~K}=$ phosphatidylinositol-3-kinase; $\mathrm{PKC}=$ protein kinase C; TFPI-2 = tissue factor pathway inhibitor 2 ; TPLC $=$ phospholipase C; TRAIL = tumor necrosis factor-related apoptosis-inducing ligand; VEGF = vascular endothelial growth factor; VEGFR = VEGF receptor; $\mathrm{WHO}=$ World Health Organization. necrosis. ${ }^{74}$ Over $90 \%$ of meningiomas are histologically benign, and these lesions are associated with a low rate of recurrence (7-20\%). ${ }^{68,74,105}$ Atypical lesions are much less common. They account for 4.7 to $7.2 \%$ of meningiomas and are associated with a $40 \%$ recurrence rate despite resection. ${ }^{105}$ Malignant meningiomas represent only 1 to $2.8 \%$ of meningiomas but recur in 50 to $80 \%$ of cases and usually result in death within 2 years of diagnosis. ${ }^{68,74}$

\section{Molecular Pathogenesis of Meningiomas}

There has been some progress in understanding the molecular genetics of meningiomas, ${ }^{68,105,119}$ but compared with our knowledge of gliomas, relatively little is known. ${ }^{135} \mathrm{Me}-$ ningiomas constitute one of the first types of solid tumors to be associated with a characteristic cytogenetic change, loss of heterozygosity of chromosome $22.68,105,141$ The $N F 2$ gene is the primary target, with mutation or deletion constituting an early event in half of sporadic and most NF2associated meningiomas. ${ }^{46,68,105}$ The NF2 gene encodes a protein, termed merlin or schwannomin, that regulates cell growth and motility by linking the cytoskeleton to cell membrane proteins ${ }^{68,105}$ Interestingly, the likelihood of NF2 mutation appears to vary with histological subtype. In a recent study, ${ }^{46} 126$ sporadic meningioma specimens were analyzed with microarray-based comparative genomic hybridization. The frequency of biallelic $N F 2$ inactivation was $52 \%$ in fibroblastic tumors compared with $18 \%$ in meningothelial tumors, both of which are benign meningioma subtypes; this finding suggests that NF2 inactivation may not be a critical step in the pathogenesis of meningothelial meningiomas. Fifty-one tumors (40\%) showed no evidence of loss of the long arm of chromosome 22 (22q), and 16 (13\%) showed partial 22q loss that did not involve the NF2 locus. These findings indicate that additional genes on $22 \mathrm{q}$ 
and elsewhere in the genome have an important pathogenic role in the development of a subset of meningiomas. Candidate genes on 22q include BCR, implicated in CML; $R g r$, an oncogene involved in Ras signaling; and the zinc finger protein-encoding gene $\mathrm{ZCWCCl} .{ }^{46}$ Like merlin, the product of the $D A L-1$ gene (DAL-1 or Protein 4.1B) may play an important role early in meningioma tumorigenesis. ${ }^{68,104,105}$ Recurrent meningiomas often are characterized by loss of 14q. ${ }^{105}$ Transition to atypical meningiomas is associated with losses on $1 \mathrm{p}, 6 \mathrm{q}, 10 \mathrm{q}, 14 \mathrm{q}, 18 \mathrm{q}$, and gains on $1 \mathrm{q}, 9 \mathrm{q}, 12 \mathrm{q}, 15 \mathrm{q}, 17 \mathrm{q}$, and $20 \mathrm{q}$, together with increased telomerase activity and loss of progesterone receptor expression. ${ }^{68,105,135}$ Malignant meningiomas are associated with gains on 17q, losses on 9p (CDKN2A/B, p14ARF), and further losses on 1p, 6q, 14q, and 18q, as well as loss of progesterone receptor expression. ${ }^{68,105,135}$

The results of gene expression profiling studies have distinguished benign meningiomas from atypical and malignant tumors and confirmed previously noted altered expression of GHR, IGFBP-7, endothelin receptor A (ET-A), and IGF-2. ${ }^{129}$ Additional genes were noted to be differentially overexpressed, including genes that encode cathepsin K (cellular protease associated with an invasive tumor phenotype), midkine (mitogenic and angiogenic factor), and ear2 (nuclear orphan receptor associated with hormonal gene regulation). Other genes such as Rad (nm23 metastasis suppressor), $B C R$, and junB (represses cyclin $\mathrm{D}$ and cell proliferation) proved to be downregulated in high-grade meningiomas. ${ }^{129}$ More recent microarray studies showed that losses on chromosomes 10 and 14 in high-grade meningiomas were associated with distinct expression profiles including increased expression of several genes related to the IGF (IGF-2, IGFBP3, and AKT3) or wingless (WNT; $C T N N B 1, C D K 5 R 1, E N C 1$, and CCND1) pathways. ${ }^{138}$ Proteomic analysis may also help to elucidate the molecular events that underlie the transition from benign to atypical or malignant meningiomas. ${ }^{101}$

In this review, the treatment of meningiomas with targeted molecular therapies will be discussed.

\section{Current Therapies for Meningiomas}

Current therapies for meningiomas involve surgery, radiation therapy, and stereotactic radiosurgery. $15,16,24,30,40,87,89,110,135$ For the majority of patients with benign meningiomas and a subset of patients with atypical meningiomas, these therapies are effective in achieving tumor control. There is, however, an important group of patients with inoperable or higher-grade tumors in whom disease recurs following surgery and radiation therapy. The treatment options for these patients are currently inadequate.

To date chemotherapy has had only a very limited role in the treatment of meningiomas. Data from small clinical trials and case series suggest that most chemotherapeutic agents have minimal activity against meningiomas. ${ }^{14,16,66,87}$ The evaluation of chemotherapy has also been complicated by the lack of data regarding the natural history of untreated meningiomas. Many chemotherapy studies have demonstrated variable periods of disease stabilization, but it is difficult to know whether this represents an improvement because benign meningiomas grow slowly and may appear radiographically stable for prolonged periods. ${ }^{49,142}$
In general, chemotherapeutic agents (such as dacarbazine and adriamycin) that have activity in other soft tissue tumors have produced disappointing results in patients with meningiomas. ${ }^{16}$ Hydroxyurea, an oral ribonucleotide reductase inhibitor, arrests meningioma cell growth in the $\mathrm{S}$ phase of the cell cycle and induces apoptosis. ${ }^{122}$ In a preliminary report, hydroxyurea (1000-1500 mg/day; $20 \mathrm{mg} /$ $\mathrm{kg} /$ day) decreased tumor size in three patients with recurrent benign meningiomas and prevented recurrent disease for 24 months in a patient with a completely resected malignant meningioma. ${ }^{123}$ Several more recent studies suggest that hydroxyurea has modest activity; responses are uncommon but some patients appear to experience disease stabilization. ${ }^{23,75,80,96,114}$ The Southwest Oncology Group conducted a Phase II study to further evaluate the role of hydroxyurea in meningiomas (SWOG-S9811). This study is closed to accrual, but the final results are not yet available.

There have been reports of small numbers of patients with malignant meningiomas who responded to recombinant interferon $\alpha-2 b$ b $^{60,90}$ Temozolomide (Temodar, Schering-Plough; TMZ), an alkylating agent with activity in malignant gliomas, was evaluated in 16 patients with refractory meningiomas and showed negligible activity. ${ }^{18}$ The topoisomerase inhibitor irinotecan (Camptosar, Pfizer; CPT-11) caused moderate toxicity in 16 patients with benign meningiomas and had no demonstrable activity. ${ }^{17}$ A large number of cytotoxic agents are under evaluation for sarcomas and other systemic malignancies. ${ }^{88}$ Most of these have not been evaluated in meningiomas, and it is possible that some may have modest activity. However, it is likely that the more novel therapeutic approaches discussed below will provide a greater chance of improving the outcome for patients with meningiomas.

\section{Challenges in the Development of Effective Therapies for Meningiomas}

In contrast to the extensive understanding of the molecular pathogenesis and biology of systemic malignancies, and even brain tumors such as malignant gliomas, relatively little is known about the molecular pathogenesis of meningiomas and the critical molecular changes driving tumor growth. ${ }^{54,68,105,119}$ Overexpression of various growth factors-including PDGF, EGF, and VEGF-and their receptors, and signal transduction pathways-such as the Ras/MAPK, PI3K-Akt, and PLC- $\gamma 1$-PKC pathwayshave been implicated, but their relative significance is largely unknown..$^{54,119}$ As a result, the most important molecular targets may remain to be elucidated.

Another factor limiting progress in the development of more effective therapies for meningiomas is the lack of robust cell lines and animal models. There is a need for animal models that replicate the genetic changes in meningiomas with a high frequency of spontaneous meningioma development, benign meningioma lines for in vitro and in vivo studies, and meningeal-specific promoters. Many of the existing meningioma cell lines are derived from malignant meningiomas and probably contain culture-induced artifacts and lack progesterone receptors. ${ }^{105}$ There are some orthotopic $^{11,85}$ and genetic models ${ }^{61}$ in development that appear promising. Recently, two cell lines were developed from benign meningioma specimens via immortalization with 
human telomerase reverse transcriptase and SV40 large T antigen. Orthotopic tumors with immunostaining patterns similar to those of human meningiomas were established from both cell lines in athymic nude mice. ${ }^{11}$ Another model uses a Cre recombinase technology to inactivate $N F 2$ in arachnoid cells, resulting in intracranial meningothelial hyperplasia and meningiomas in $30 \%$ of mice. ${ }^{61}$ These models may aide in the preclinical evaluation of novel therapies.

The lack of data regarding the natural history of untreated meningiomas is another important limiting factor that impedes progress. Without such data it is difficult to know if the periods of disease stabilization reported in various studies represent an improvement over no therapy.

A final factor limiting progress is the relatively small number of patients with meningiomas who require additional therapies after treatment with surgery and radiation therapy. In general, there is little incentive for pharmaceutical companies to evaluate their therapies in meningiomas because of the small potential market. It is hoped that, as the molecular pathogenesis of these tumors becomes better understood, a compelling case can be made for evaluating specific agents directed at critical molecular targets.

In the next section, targeted molecular drugs that have a potential role against meningiomas will be reviewed in detail. These therapies have been discussed in other recent reviews. ${ }^{54,87,110,131}$

\section{Molecular Targets and Related Agents}

Recently, it has become apparent that many human diseases result from aberrations in cell signaling pathways. Protein tyrosine kinases play a fundamental role in signal transduction, and deregulated activity of these enzymes has been observed in many cancers. Therefore, specific inhibitors of tyrosine kinases could have therapeutic applications in the treatment of cancer, with potentially lower toxicity and/or higher, prolonged response rates. ${ }^{2,31}$ The prototypical targeted molecular agent is imatinib mesylate (Gleevec, Novartis), which has shown significant benefit in $\mathrm{CML}^{29}$ and gastrointestinal stromal tumors. ${ }^{25}$ There is also a growing experience with targeted molecular agents in malignant gliomas. ${ }^{19,62,132}$ To date, however, there have been minimal data on the use of these agents in meningiomas.

In contrast to the extensive work on understanding the genetics of meningiomas, relatively little work has been conducted in understanding the growth factors, their receptors, and the signal transduction pathways that are critical to meningioma growth. ${ }^{54,87,110}$ Platelet-derived growth factor, EGF, VEGF, IGF, TGF- $\beta$, and their receptor tyrosine kinases, together with their downstream signaling pathways including the Ras/MAPK pathway, the PI3K/Akt pathway, the PLC- $\gamma 1$-PKC pathway, and the TGF- $\beta$ SMAD pathways, are all thought to be important in meningioma growth (Fig. 1). ${ }^{54}$

\section{Platelet-Derived Growth Factor Receptors}

Platelet-derived growth factor is a fundamental driver of cell proliferation in normal development and in a variety of pathological conditions, including cancer. ${ }^{106}$ Accumulating evidence suggests that PDGF plays an important role in meningioma growth., ${ }^{62,92,128,139}$ Most meningiomas of all histological grades express PDGF ligands AA and BB and the PDGF- $\beta$ receptor. ${ }^{6,82,92,128,139}$ Expression levels may be higher in atypical and malignant meningiomas than in benign meningiomas. ${ }^{139}$ Laboratory data suggest that an autocrine PDGF loop supports meningioma cell growth and maintenance. ${ }^{82}$ When PDGF-BB is applied to cultured meningioma cells, MAPK ${ }^{58}$ and c-fos ${ }^{63}$ are activated and tumor cell proliferation is enhanced. Conversely, anti-PDGF-BB antibodies inhibit cell growth. ${ }^{127}$ These data provide a sound rationale for testing PDGF inhibitors in meningioma patients.

Imatinib is a potent inhibitor of the Bcr-Abl, PDGF- $\alpha$ and PDGF- $\beta$ receptors, and c-Kit tyrosine kinases..$^{10}$ Its ability to inhibit PDGFR with an $\mathrm{IC}_{50}$ of $0.1 \mu \mathrm{M}$ suggests that it may have therapeutic potential in meningiomas. The NABTC conducted a Phase II study of imatinib in patients with recurrent meningiomas (NABTC 01-08). ${ }^{134}$ Patients were stratified into two cohorts: 1) those with benign meningiomas, and 2) those with atypical and malignant meningiomas. As imatinib is metabolized by the cytochrome P450 system (3A4), patients could not be receiving enzyme-inducing AEDs. Patients initially received 600 $\mathrm{mg} /$ day of imatinib; the dose was increased in the second cycle to $800 \mathrm{mg} /$ day if no significant toxicity was observed in the first cycle. Twenty-three patients were enrolled into the study (13 with meningiomas, five with atypical meningiomas, and five with malignant meningiomas). Although the treatment was generally well tolerated, imatinib had minimal activity. Of the 19 patients in whom response could be evaluated, 10 had experienced disease progression at the first scan; in the other nine the disease was stable. There were no radiographic responses. Overall median duration of progression-free survival was 2 months (range $0.7-18$ months); the 6-month progression-free survival rate was $29.4 \%$. For benign meningiomas, median duration of progression-free survival was 3 months and the 6-month rate was $45 \%$. For the atypical and malignant meningiomas, median progression-free survival was 2 months and the 6-month rate was $0 \%$. Several other inhibitors of PDGF are undergoing evaluation, including sunitinib, MLN518, dasatinib, AMN 107, pazopanib, sorafenib, CP673451, and CHIR 265. Some of these, such as MLN518, are more potent PDGFR inhibitors than imatinib, whereas others target additional kinases that are potentially important in meningiomas. For example, sunitinib and pazopanib also inhibit VEGFR 1, 2, and 3 as well as c-Kit, while sorafenib and CHIR 265 inhibit VEGFR, c-Kit and Raf. These drugs may be more effective than imatinib as monotherapy against meningiomas.

There is also interest in combining imatinib with hydroxyurea, the cytotoxic chemotherapy agent with the most activity in meningiomas. Although a recent Phase I/II trial of imatinib as monotherapy for recurrent malignant glioma showed minimal activity, ${ }^{133}$ encouraging results have been reported for a study in which 33 patients with recurrent glioblastoma multiforme were treated with both imatinib mesylate $(400 \mathrm{mg} /$ day or $500 \mathrm{mg}$ twice/day, depending on concurrent use of enzyme-inducing AEDs) and hydroxyurea (500 mg twice/day). ${ }^{12}$ After a median follow up of 58 weeks, a complete response was achieved in one case, a partial response in two cases, and the disease was stable in 14 cases. The 6-month progression-free survival rate was $27 \%$. 
A. D. Norden, J. Drappatz, and P. Y. Wen

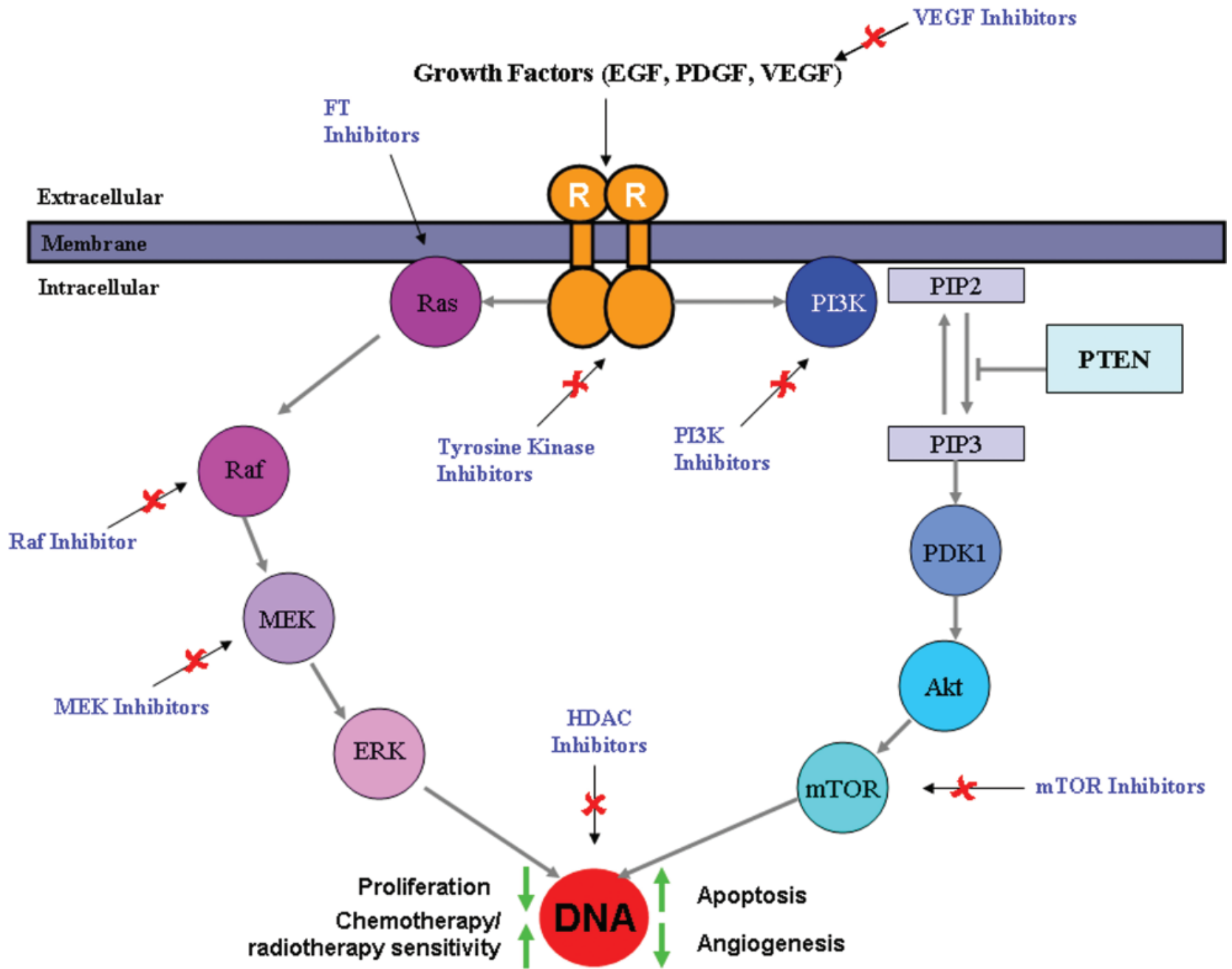

FIG. 1. Selected signaling pathways in meningiomas and molecular targets for drug therapy. ERK = extracellular signal-regulated kinase; FT = farnesyltransferase; HDAC = histone deacetylase; PDK1 = 3-phosphoinositide-dependent protein kinase 1; PIP2 = phosphatidylinositol (4, 5)-bisphosphate; PIP3 = phosphatidylinositol (3, 4, 5)-trisphosphate; PTEN = phosphatase and tensin homologue deleted on chromosome 10. Adapted from: Expert Rev Anticancer Ther 6:733-754, 2006, with permission of Future Drugs Ltd.

\section{Epidermal Growth Factor Receptor}

The EGFR is overexpressed in more than $60 \%$ of meningiomas. . $12,55,59,72,118,130$ Both EGF and TGF- $\alpha$ activate these receptors and stimulate meningioma growth in vitro, ${ }^{54,55,130}$ supporting the concept that activation of EGFRs in human meningiomas by autocrine/paracrine stimulation may contribute to the proliferation of these lesions. Increased TGF$\alpha$ immunoreactivity in meningiomas has been associated with aggressive growth..$^{51,54,72}$

The NABTC conducted two trials of EGFR inhibitors in the treatment of meningiomas. In NABTC 01-03, patients with recurrent or progressive meningiomas who were not being treated with enzyme-inducing AEDs were treated with $150 \mathrm{mg} /$ day of erlotinib (Tarceva, Genentech). In NABTC 00-01, patients with recurrent or progressive meningiomas who were not being treated with enzyme-inducing AEDs were treated with $500 \mathrm{mg} /$ day of gefitinib (Iressa, AstraZeneca). In both studies, the drugs were reasonably well tolerated; the main signs of toxicity were the expected adverse effects of rash and diarrhea. Both studies have been closed to accrual, but the final results are not yet available.

In addition to gefitinib and erlotinib, a large number of other agents are currently undergoing evaluation for the treatment of other tumors. These inhibit EGFR alone or together with other receptor tyrosine kinases that may have therapeutic potential in meningiomas (Table 1). For example, lapatinib inhibits EGFR and HER2, HKI-272 inhibits all subtypes of the EGFR, and ZD6474 (Zactima, AstraZeneca) inhibits EGFR and VEGFR.

Although EGFR monoclonal antibodies have been effective for some systemic malignancies (for example, cetuximab in colorectal cancer), they have generally not been used for brain tumors because of concern regarding the ability of these agents to pass through the blood-brain barrier in sufficient concentrations to produce a therapeutic effect. Since the blood-brain barrier is not a factor in most meningiomas, it is possible that these antibodies may be 
TABLE 1

Selected potential targeted molecular therapies for the treatment of meningiomas*

\begin{tabular}{|c|c|}
\hline $\begin{array}{l}\text { Apoptosis Enhancers } \\
\text { ABT737 (Bcl-2 inhibitor) } \\
\text { AT101 (Bcl-2 inhibitor) } \\
\text { fenretinide (multiple targets) } \\
\text { GX15-070 (Bcl-2 inhibitor) }\end{array}$ & $\begin{array}{l}\text { mTOR Inhibitors } \\
\text { AP23573 } \\
\text { everolimus (RAD001) } \\
\text { rapamycin } \\
\text { temsirolimus (CCI-779) }\end{array}$ \\
\hline $\begin{array}{l}\alpha V \beta 3 \text { and } \alpha V \beta 5 \text { Integrin Inhibitor } \\
\text { cilengitide }\end{array}$ & $\begin{array}{l}\text { PDGFR Inhibitors } \\
\text { AMN } 107 \text { (c-Kit, Bcr-Abl inhibitor) }\end{array}$ \\
\hline $\begin{array}{l}\text { Cell-Cycle Inhibitors } \\
\text { AG024322 (pan-CDK inhibitor) } \\
\text { AZ703 (CDK 2, } 1 \text { inhibitor) } \\
\text { BMS-387032 (CDK 2, } 1 \text { inhibitor) } \\
\text { CINK4 (CDK 4, } 6 \text { inhibitor) } \\
\text { E7070 } \dagger \\
\text { flavopiridol (pan-CDK inhibitor) } \\
\text { PD-0332991 (CDK 4, } 6 \text { inhibitor) } \\
\text { seliciclib (CDK 2, } 1 \text { inhibitor) }\end{array}$ & $\begin{array}{l}\text { CHIR } 265 \text { (Raf, VEGFR, c-Kit inhibitor) } \\
\text { CP-673-451 } \\
\text { dasatinib (Src, c-Kit, ephrin A inhibitor) } \\
\text { imatinib mesylate (Gleevec) } \\
\text { MLN518 (c-Kit inhibitor) } \\
\text { pazopanib (GW786034; VEGFR, c-Kit inhibitor) } \\
\text { sunitinib (Sutent; VEGFR, c-Kit inhibitor) } \\
\text { vatalanib (PTK787; VEGFR inhibitor) } \\
\text { XL-999 (VEGFR, FGFR inhibitor) }\end{array}$ \\
\hline $\begin{array}{l}\boldsymbol{c} \text { - } \boldsymbol{M E T}(\boldsymbol{H G F} / \mathbf{S F}) \text { Inhibitors } \\
\text { AMG-102 } \\
\text { XL880 (VEGFR2, PDGFR, c-Kit, Tie-2 inhibitor) }\end{array}$ & $\begin{array}{l}\text { PKC } \boldsymbol{\beta 2} \text { Inhibitor } \\
\text { enzastaurin (LY31761) } \\
\text { PI3K Inhibitor } \\
\text { BEZ235 }\end{array}$ \\
\hline $\begin{array}{l}\text { EGFR Inhibitors } \\
\text { AEE788 (VEGFR inhibitor) } \\
\text { BIBW } 2992 \text { (HER2 inhibitor) }\end{array}$ & $\begin{array}{l}\text { Proteosome Inhibitor } \\
\text { bortezomib (Velcade) }\end{array}$ \\
\hline $\begin{array}{l}\text { cetuximab (Erbitux) } \\
\text { EMD } 72000\end{array}$ & $\begin{array}{l}\text { Raf Kinase Inhibitor } \\
\quad \text { sorafenib (Nexavar, BAY 43-9006; VEGFR, PDGFR inhibitor) }\end{array}$ \\
\hline $\begin{array}{l}\text { erlotinib (OSI-774, Tarceva) } \\
\text { gefitinib (ZD1839, Iressa) } \\
\text { HKI-272 (pan-EGFR inhibitor) }\end{array}$ & $\begin{array}{l}\text { Src Inhibitors } \\
\quad \text { AZD0530 } \\
\text { dasatinib }\end{array}$ \\
\hline $\begin{array}{l}\text { lapatinib (GW-572016; ErbB2 inhibitor) } \\
\text { mAb } 806 \\
\text { nimotuzumab (TheraCIM) } \\
\text { panitumumab (Vectibix) } \\
\text { ZD6474 (Zactima; VEGFR inhibitor) }\end{array}$ & $\begin{array}{l}\text { TGF }-\boldsymbol{\beta} / \mathbf{T G F}-\boldsymbol{\beta} \text { Receptor Inhibitors } \\
\text { AP12009 } \\
\text { GC1008 } \\
\text { SB-431542 }\end{array}$ \\
\hline $\begin{array}{l}\text { Endothelin-A Inhibitors } \\
\text { astrasentan (Xinlay) } \\
\text { ZD4054 }\end{array}$ & $\begin{array}{l}\text { VEGF Inhibitors } \\
\text { bevacizumab (Avastin) } \\
\text { VEGF trap }\end{array}$ \\
\hline $\begin{array}{l}\text { Farnesyltransferase Inhibitors } \\
\text { lonafarnib (SCH 66336, Sarasar) } \\
\text { tipifarnib (R115777, Zarnestra) }\end{array}$ & $\begin{array}{l}\text { VEGFR Inhibitors } \\
\text { AEE788 (EGFR inhibitor) } \\
\text { AG013736 } \\
\text { AMG } 706\end{array}$ \\
\hline $\begin{array}{l}\text { Histone Deacetylase Inhibitors } \\
\text { depsipeptide } \\
\text { voronistat (SAHA) } \\
\text { valproic acid }\end{array}$ & $\begin{array}{l}\text { AZD2171 } \\
\text { CEP-7055 } \\
\text { CHIR } 265 \text { (Raf, PDGFR, c-Kit inhibitor) } \\
\text { CHIR-258 (PDGFR, FGFR, c-Kit, FLT-3 inhibitor) }\end{array}$ \\
\hline $\begin{array}{l}\text { HSP90 Inhibitors } \\
\text { 17AAG } \\
\text { 17DMAG } \\
\text { IPI504 }\end{array}$ & $\begin{array}{l}\text { GW786034 (c-Kit inhibitor) } \\
\text { sorafenib (Nexavar, BAY 43-9006; Raf kinase, PDGFR inhibitor) } \\
\text { sunitinib (Sutent; PDGFR, c-Kit inhibitor) } \\
\text { vatalanib (PTK787; PDGFR inhibitor) }\end{array}$ \\
\hline $\begin{array}{l}\text { MEK Inhibitors } \\
\text { AZD6244 } \\
\text { PD0325901 }\end{array}$ & $\begin{array}{l}\text { XL-999 (PDGFR, FGFR inhibitor) } \\
\text { ZD6474 (Zactima; EGFR inhibitor) }\end{array}$ \\
\hline
\end{tabular}

* Additional names and mechanisms of action are given in parentheses. Proprietary information for therapeutic agents discussed is given at the first mention in the text except for the following, which are only mentioned in this table: Erbitux (Bristol-Myers Squibb and ImClone Systems), TheraCIM (YM BioSciences), Vectibix (Amgen), Velcade (Millenium). Abbreviations: FGFR = fibroblast growth factor receptor; $\mathrm{SAHA}=$ suberoylanilide hydroxamic acid; TGF $\beta \mathrm{R}=\mathrm{TGF}-\beta$ receptor.

$\dagger$ The mechanism by which this agent inhibits the cell cycle is unknown.

effective in these tumors. To date very few studies have evaluated the therapeutic potential of these agents in meningiomas. In a Phase I study of a murine monoclonal antibody against EGFR in nine patients with either gliomas or meningiomas, treatment was reasonably well tolerated. No radiographic responses were detected, but efficacy data are difficult to interpret in a study involving so few patients. ${ }^{21}$ Currently, several anti-EGFR antibodies-including cetuximab, panitumumab, EMD 72000, nimotuzumab, and $\mathrm{mAb}$ 806 - are under evaluation for other malignancies. Trials of these agents in meningiomas may be worthwhile, especially if combined with correlative studies examining whether the antibodies can achieve therapeutic concentrations in meningiomas and inhibit EGFR in vivo.

The MAPK Pathway

Signal transduction from activated tyrosine kinases such as EGFR and PDGFR is mediated in part by the Ras/Raf/ MAPK pathway and the PI3K/Akt pathways. Meningioma growth is stimulated in vitro by PDGF-BB via the MAPK pathway, which is constitutively activated in benign meningiomas and meningioma cell cultures. ${ }^{58}$ Treatment with PD098059, an MEK inhibitor, reduces MAPK phosphorylation, inhibits meningioma growth in vitro, and prevents PDGF-BB stimulation of meningioma growth. ${ }^{58}$ The MAPK pathway is also activated in some, but not all, atypical and malignant meningiomas, ${ }^{81}$ suggesting that other signal transduction pathways may also be involved. A number of Raf inhibitors (for example, sorafenib) and MEK inhibitors (for example, PD098059 and AZD6244) are undergoing clinical evaluation and may have roles in the treatment of meningiomas. Activation of Ras requires localization to the cytoplasmic surface of the cell membrane. ${ }^{1}$ This subcellular localization is dependent on the 
addition of a hydrophobic farnesyl group to the Ras protein, catalyzed by the enzyme farnesyltransferase. Farnesyltransferase inhibitors, such as tipifarnib (Zarnestra, Johnson \& Johnson) and lonafarnib (Sarasar, Schering-Plough) inhibit the Ras pathway, and may have therapeutic potential in meningiomas. Nevertheless, preliminary studies suggest that the activity of these agents may be limited in benign meningiomas. ${ }^{54}$

\section{The PI3K/Akt Pathway}

The PI3K/Akt pathway plays a central role in many malignancies. ${ }^{22,32}$ Both Akt and $\mathrm{p} 70^{\mathrm{s} 6 \mathrm{~K}}$ are expressed and activated (phosphorylated) in benign meningiomas and play a role in signal transduction from PDGFR stimulated by PDGF-BB. ${ }^{57}$ Treatment with a PI3K inhibitor has been found to produce a dose-dependent inhibition of PDGF-BB stimulation, with a concomitant attenuation of Akt and p70 ${ }^{\mathrm{s} 6 \mathrm{~K}}$ phosphorylation. ${ }^{54,57}$ Phospho-Akt is present in higher levels in atypical and malignant meningiomas than in benign meningiomas. ${ }^{81}$ Inhibition of PI3K has resulted in reduction in phospho-Akt activity in atypical and malignant meningiomas. ${ }^{81}$ These results suggest that the PI3K/Akt pathway may play a central role in meningiomas, especially in atypical and malignant meningiomas. Inhibitors of PI3K (for example, BEZ235), inhibitors of Akt (for example, perifosine), and mTOR inhibitors (for example, sirolimus, temsirolimus [CCI-779], everolimus [RAD001], and AP23573) may have therapeutic potential in these tumors.

\section{The PLC- $\gamma 1-P K C$ Pathway}

In addition to activating the MAPK and the PI3K/Akt pathways, receptor tyrosine kinases such as EGFR and PDGFR also activate PLC- $\gamma 1-P K C .{ }^{54}$ Activation of PLC$\gamma 1-\mathrm{PKC}$ results in hydrolysis of phosphatidylinositol-4,5diacylglycerol to inositol 1,4,5-triphosphate and 1,2-diacylglycerol. The 1,2-diacylglycerol activates PKC and the MAPK and PI3K/Akt pathways. ${ }^{54,55}$ The PKC enters the nucleus and activates c-fos and c-jun, leading to cell proliferation and inhibition of apoptosis. ${ }^{54}$ Activation of EGFR on meningioma cells results in phosphorylation of PLC- $\gamma 1.55$ The interaction of PLC- $\gamma 1$ with the MAPK and the PI3K/ Akt pathways underscores the complexities of the signaling pathways and the likelihood that inhibition of multiple targets will be necessary.

\section{The TGF- $\beta$-SMAD Signaling Pathways}

The precise role of TGF- $\beta$ in meningiomas remains to be defined. Meningiomas secrete TGF- $\beta 1,2$, and 3 , and possess functional TGF- $\beta$ type I and II receptors. ${ }^{54,56}$ Transforming growth factor- $\beta 1$ inhibits proliferation of leptomeningeal and benign meningioma cells via signal transduction through the SMAD 2/3 pathway. ${ }^{54,56}$ In other tumors, including gliomas, higher-grade tumors change from being inhibited to being stimulated by TGF- $\beta .{ }^{54}$ Whether a similar process occurs in meningiomas is unclear. If TGF- $\beta$ plays an activating role in high-grade meningiomas, evaluating such inhibitors of TGF- $\beta$ as SB-431542, AP12009, and GC1008 may be worthwhile.

\section{Cell Cycle Inhibitors}

Recently, there has been progress in identifying agents that target the cell cycle to treat cancer. ${ }^{124,125}$ Cyclin-dependent kinase activity can be inhibited by agents that competitively inhibit CDK ATP-binding pockets or that allosterically modulate CDK or endogenous CDK inhibitor complexes. Singleagent activity has been modest to date, but newer oral agents that allow long-term dosing and combinations of CDK inhibitors with other targeted agents or cytotoxic agents may hold greater promise..$^{124,125}$

\section{Apoptosis Modulators}

Defects in programmed cell death (apoptosis) mechanisms play an important role in tumor pathogenesis and resistance to therapy. ${ }^{95,113,115,132}$ Apoptosis occurs via two main mechanisms. The extrinsic pathway is characterized by activation of death receptors with subsequent activation and cleavage of caspase 8 . The intrinsic pathway is characterized by depolarization of the mitochondrial membrane, activation of caspase 9 and then caspase 3 and other executioner caspases. ${ }^{95,113,115}$ There has been increasing interest in identifying targeted agents that modulate apoptosis to destroy tumor cells. $38,95,113,115$ This modulation can be achieved either by inhibiting pro-survival pathways such as the Akt and MAPK pathways and $\mathrm{NF \kappa} B$, or by inducing apoptosis. The activation of cell surface receptors by TRAIL leads to stimulation of the extrinsic pathway. ${ }^{115}$ Agents that activate these receptors, such as monoclonal antibodies to TRAIL receptors and recombinant TRAIL, are being evaluated as monotherapies and in combination with chemotherapeutic agents. ${ }^{15}$

The Bcl-2 family of proteins plays a central regulatory role in the intrinsic pathway. Overexpression of Bcl-2 or BclXL renders tumor cells resistant to apoptotic stimuli, including many cytotoxic agents. Strategies to inhibit these proteins with small molecules such as ABT-737, ${ }^{102} \mathrm{Bcl}-2$ antisense, ${ }^{107}$ and $\mathrm{BH} 3$ mimetic peptides ${ }^{71}$ are being evaluated.

The IAPs are endogenous apoptosis suppressors, many of which function as caspase inhibitors. ${ }^{113}$ A number of inhibitors of IAPs are in development; they represent a promising class of agents with antitumor activity that may be synergistic with conventional cytotoxic therapies and other targeted molecular agents. ${ }^{113,120,121}$ To date these agents have not been evaluated in meningiomas.

Another class of agents that may have therapeutic potential in meningiomas is synthetic retinoids, such as fenretinide, that induce apoptosis in tumor cells. ${ }^{109} \mathrm{In}$ an in vitro study, fenretinide induced apoptosis in all three histological subtypes of meningioma and exerted diverse cellular effects, including DR5 upregulation, modulation of retinoid receptor levels, and inhibition of IGF-1-induced proliferation. ${ }^{109}$

\section{Inhibition of Angiogenesis}

Meningiomas are highly vascular tumors that derive their blood supply predominantly from meningeal vessels supplied by the external carotid artery, with additional supply from cerebral pial vessels.$^{68}$ Inhibition of angiogenesis has become an increasingly important approach to treating cancer. ${ }^{34}$ Studies evaluating inhibitors of angiogenesis in meningiomas are limited. In one early study, ${ }^{140}$ investiga- 
tors found that TNP-470, a fumigillin analogue, inhibits the growth of benign and malignant meningioma xenografts in nude mice.

Vascular endothelial growth factor plays a central role in tumor angiogenesis, and there is increasing evidence that inhibition of VEGF or VEGFR can lead to significant antitumor effects. ${ }^{34}$ Inhibition of VEGF with the anti-VEGF antibody bevacizumab (Avastin, Genentech) has significantly improved survival in several malignancies including colorectal, lung, and breast cancer..$^{53}$ Inhibitors of VEGFR such as sorafenib (Nexavar, Bayer) and sunitinib (Sutent, Pfizer) have also prolonged survival in patients with renal cell carcinoma and gastrointestinal stromal tumors. ${ }^{53}$ Vascular endothelial growth factor and VEGFR are expressed in meningiomas, and the level of expression increases with tumor grade. . $^{39,69,108}$ Expression of VEGF is increased twofold in atypical meningiomas and 10-fold in malignant meningiomas compared with benign meningiomas. ${ }^{69}$ Vascular endothelial growth factor also plays an important role in the formation of peritumoral edema, which adds to the morbidity of these tumors. ${ }^{39,108}$ Inhibitors of VEGF and VEGFR are promising agents in meningioma treatment, with the potential not only to inhibit angiogenesis, but also to decrease peritumoral edema. A multicenter Phase II study of sunitinib in patients with recurrent or inoperable meningiomas is expected to open soon at Dana-Farber/Brigham and Women's Cancer Center and Memorial Sloan-Kettering Cancer Center. Sunitinib is a theoretically appealing agent for meningioma treatment because it is a multiple tyrosine kinase inhibitor that targets both VEGFR and PDGFR (in addition to c-Kit and the FLT3 and RET kinases). During each 6-week cycle, patients will receive sunitinib $(50 \mathrm{mg} /$ day) daily for 4 weeks followed by 2 weeks without treatment. Levels of serum biomarkers will be assessed, tumor expression profiling will be performed, and perfusion magnetic resonance images will be obtained (although it is not yet clear if the imaging studies will be performed in all cases) with the goal of developing predictors of response. A trial of sorafenib, which also targets VEGFR and PDGFR, is in progress.

Other angiogenic factors implicated in meningiomas include fibroblast growth factor, ${ }^{69}$ placental growth factor, ${ }^{27}$ and possibly HGF/SF, although the role of the latter is less clear. ${ }^{69,79}$ The presence of HGF/SF and its receptor c-MET appears to be associated with an increased proliferation index and rate of recurrence. ${ }^{79}$

Endothelins are peptides that promote tumor progression by several mechanisms, including angiogenesis, cell proliferation, inhibition of apoptosis, and matrix remodeling. Several isoforms are known, including ET-1, ET-2, and ET-3. The ETs function via two G-protein-coupled receptors, ETA and ET-B.,47 Both ET-1 and ET-A are overexpressed in meningiomas. ${ }^{47,103}$ The growth of primary meningioma cultures can be blocked by the ET-A inhibitor BQ-123 but not by the ET-B inhibitor RES-701-3, which suggests that the effects of ET-1 on meningioma growth are mediated by ETA receptors. ${ }^{103}$ Several ET-A receptor antagonists are under development, including astrasentan (Xinlay, Abbott) and ZD4054, but they have not yet been tested in meningiomas.

\section{Inhibition of Invasion}

Brain invasion is a characteristic of meningiomas, espe- cially high-grade tumors. ${ }^{68,105}$ Meningiomas overexpress matrix metalloproteinases, such as MMP-2 and 9,99,126 SPARC, tenascin, and stremelysin-3, ${ }^{105}$ while malignant meningiomas overexpress TFPI-2 ${ }^{65}$ Tissue factor pathway inhibitor-2 is an extracellular matrix-associated Kunitztype serine proteinase inhibitor secreted by all vascular cells. It plays a role in tumor invasion and metastasis, presumably by plasmin-mediated matrix remodeling. Previous studies showed that expression of TFPI-2 is lost in highgrade tumors, including gliomas. Transfection of TFPI-2 mRNA into the human meningioma cell line IOMM-Lee inhibited tumor growth in vitro and in vivo, which suggests that TFPI-2 may have therapeutic potential in malignant meningiomas. ${ }^{65}$ Other invasion inhibitors have been studied for the treatment of systemic cancers and gliomas, and some of these agents may have a therapeutic effect in meningiomas. ${ }^{70,93,111,117}$ One such agent is cilengitide, an inhibitor of $\alpha \mathrm{V} \beta 3$ and $\alpha \mathrm{V} \nu \beta 5$ integrins, both of which are expressed in meningiomas ${ }^{5}$ and are potentially important for angiogenesis and invasion. The drug is in clinical trials for the treatment of gliomas, where it has been well tolerated and appears to show evidence of activity. ${ }^{91}$

\section{Other Molecular Targets}

Other potentially attractive therapeutic targets in meningiomas include IGFR-2, ${ }^{97,98}$ histone deacetylase, ${ }^{73} \mathrm{NF \kappa B},{ }^{94}$ HSP90 ${ }^{42}$ JAK/STAT, ${ }^{77}$ checkpoint kinase ${ }^{76}$ and possibly Src kinase, ${ }^{50}$ focal adhesion kinase, ${ }^{86}$ and hypoxia-inducible factor $1 \alpha .{ }^{100}$ As with gliomas and other solid tumors, the complexity of the molecular abnormalities in meningiomas and the redundancy of the signaling pathways make it improbable that single agents will achieve the same success as imatinib in CML. ${ }^{132}$ Nonetheless, the use of targeted molecular agents remains a promising and largely unexplored area in the treatment of meningiomas. It will be important to improve our understanding of the molecular pathogenesis of meningiomas and to identify the critical molecular abnormalities driving tumor growth that can be targeted. Multitargeted "dirty" drugs, combinations of targeted agents inhibiting complementary molecular targets, or the combination of targeted agents with conventional cytotoxic agents and especially radiation therapy will lead to greater antitumor effects than single agents alone. ${ }^{9,116,132}$

The results of preclinical studies suggest that radiation sensitivity can be regulated by growth factors (EGFR, IGFR), signal transduction pathways (Ras/MAPK, PI3K/ Akt), checkpoint activation and DNA repair (ATM, Chk1, $\operatorname{Rad}$ 51), and apoptosis-related proteins (Fas, BcL2). ${ }^{9}$ Many of these can be inhibited by targeted molecular agents.

Heat shock protein 90 acts as a molecular chaperone protein that is required for maturation and stability of various client proteins including EGFR, Akt, Raf, p53, and CDK4. By blocking HSP90, 17AAG enhances radiation sensitivity in several tumor cell lines. This agent and other HSP90 inhibitors may have therapeutic potential in meningiomas. ${ }^{42,116}$

There is also increasing evidence that angiogenesis inhibitors may enhance radiation sensitivity. ${ }^{20,132}$ Possible mechanisms for the beneficial effects of angiogenesis inhibition include direct antitumor effects, endothelial cell radiosensitization resulting in damaged tumor vasculature, and improved oxygenation as a result of elimination of in- 
effective tumor vessels and decreased interstitial pressure. ${ }^{136}$ Specific angiogenesis inhibitors with potential radiosensitizing effects include vandetinib (ZD6474), an inhibitor of VEGFR and EGFR; vatalanib (PTK787), an inhibitor of VEGFR and PDGFR; enzastaurin (LY317615), an inhibitor of PKC- $\beta 2$ and PI3K/Akt; and bevacizumab, a monoclonal antibody against VEGF.

\section{Hormonal Targets}

There has been longstanding interest in the possible role of sex hormones in meningioma growth. This interest is the result of several observations: 1) Meningiomas are twice as common in women. 2) Increased growth of meningiomas may occur in pregnancy and in the luteal phase of the menstrual cycle. 3) The incidence of meningiomas is slightly increased in patients with breast cancer. ${ }^{7,68}$ Estrogen receptors are present at low levels in approximately $10 \%$ of meningiomas, while progesterone and androgen receptors are present in approximately two thirds of meningiomas and are more frequently expressed in women than in men..$^{52,68 \text {, }}$ ${ }_{83,119}$ Progesterone receptors are expressed predominantly in benign meningiomas with low proliferation indices; ${ }^{137}$ they are infrequently expressed in atypical and malignant meningiomas. Because meningiomas express only low levels of estrogen receptors, the expression of progesterone receptors is probably not regulated in an estrogen-dependent manner, as is the case in breast cancer. ${ }^{105}$

Over the past two decades there have been several studies evaluating antihormonal agents in meningiomas. Given the low level of estrogen receptor expression, it is not surprising that studies with antiestrogens did not show any efficacy. ${ }^{41,78}$ In one study of tamoxifen for refractory meningioma, partial or minor responses were observed in three of 19 patients. ${ }^{41}$ Because of the high likelihood of progesterone receptor expression in most meningiomas, there has been substantial interest in progesterone receptor inhibitors. ${ }^{43}$ Initial studies of the antiprogesterone agent mifepristone (RU486) were encouraging. In one study, four of 14 patients had a minor decrease in the size of the tumor, and one patient had objective clinical improvement. ${ }^{45}$ In another study three of 10 patients experienced stabilization of disease with mifepristone treatment and tumor size decreased minimally in another three. ${ }^{67}$ Nevertheless, a prospective randomized multicenter study conducted by the Southwest Oncology Group failed to demonstrate any treatment effect; the median survival was 31 months, and 42 of 45 patients experienced disease progression with a median time to progression of 6 months. ${ }^{44}$ Mifepristone's lack of efficacy may be explained in part by the loss of progesterone receptor expression observed in meningiomas with increased proliferation index and histological grade. This is relevant because patients who are enrolled into clinical studies are more likely to have these advanced types of tumors than other types.

To date there have been no published trials of androgen receptor antagonists in meningiomas. In a small unpublished study conducted at Brigham and Women's Hospital, no responses were seen in six patients with recurrent meningiomas treated with the anti-androgen flutamide, although two patients experienced disease stabilization for almost 1 year.

There has been interest in the effect of GH on meningiomas since the initial observation that the incidence of meningiomas may be increased in patients with acromegaly. ${ }^{110}$ Growth hormone secreted by the pituitary gland stimulates the synthesis of IGF-1 in the liver, and together they facilitate normal growth. ${ }^{110}$ Growth hormone receptors are ubiquitous in meningiomas, and GHR inhibition decreases tumor growth. ${ }^{35,36,84,110}$ Pegvisomant, a pegylated GH analog that acts as a competitive GHR antagonist, significantly inhibited the growth of meningioma xenografts in nude mice. ${ }^{84}$ Tumor IGF-1 concentrations did not vary with pegvisomant treatment, and there was no autocrine IGF-1 production by the tumors. The antitumor effect was thought to be a consequence of decreased IGF-1 in the circulation or surrounding host tissue or both. Direct blockade of the GHR on tumor cells may also contribute to the antitumor effect. Whether pegvisomant can inhibit meningioma growth in patients remains to be established. In a single patient with acromegaly and a meningioma, the tumor continued to grow despite several years of treatment with pegvisomant. ${ }^{28}$

Somatostatin receptors, especially the sst2A subtype, are present on most meningiomas, although their functional role remains unclear. The addition of somatostatin inhibits meningioma growth in vitro in some studies, but increases meningioma proliferation in others. ${ }^{13}$ Radiolabeled octreotide, a long-acting somatostatin agonist, has been used in imaging studies of meningiomas. ${ }^{48,64}$ There have been anecdotal reports of octreotide inhibiting growth in human meningiomas, ${ }^{37}$ but the results are difficult to interpret in light of very small numbers. In a recent study, seven patients with recurrent meningiomas were treated with a sustainedrelease somatostatin preparation (Sandostatin LAR, Novartis). ${ }^{33}$ Indium 111-octreotide single photon emission computed tomography scanning was used to confirm the presence of somatostatin receptors in the tumors. Patients received monthly injections of sustained-release somatostatin (20-30 mg/month). Four of the seven patients experienced clinical and radiographic responses. A large-scale trial evaluating this approach is in progress.

Pasireotide (SOM230) is a novel, orally administered, somatostatin analog with a wider somatostatin receptor spectrum (including subtypes 1, 2, 3, and 5) and higher affinity (particularly for subtypes 1,3 , and 5) than the sustained-release somatostatin just described. ${ }^{8}$ A Phase II trial for patients with recurrent or progressive meningiomas is planned. Biomarkers that may serve as predictors of efficacy or toxicity will be evaluated in all patients.

\section{Looking to the Future}

As the numbers of potential molecular targets, targeted agents, and drug combinations increase dramatically, our ability to evaluate agents preclinically and to select only the most promising ones for clinical trials becomes increasingly important. This is especially imperative for meningiomas because the relevant patient population is small and limited resources have been devoted to the study of this tumor. Further development of predictive meningioma cell lines and animal models for screening drugs is crucial. Clinical trial designs must be optimized with increased use of tumor tissue to verify that adequate drug levels are achieved in the tumor and that putative targets are appropriately inhibited in vivo. Additionally, more effective correlations of response to treatment and tumor genotype must 
be routinely included in clinical trials of targeted agents. These data will ultimately enable physicians to individualize targeted drug choices on the basis of the tumor's genetic profile.

\section{Conclusions}

Despite advances in surgery, radiation therapy, and radiosurgery, there remains a small but important subset of patients with meningiomas in whom the disease recurs and in whom the recurrent tumors are refractory to conventional therapies. Chemotherapies have minimal activity and hormonal therapies have proven to be largely ineffective. Progress in identifying alternative forms of therapy for these patients with recurrent meningiomas has been limited by poor understanding of the molecular pathogenesis of meningiomas and of the critical molecular changes driving tumor growth, as well as by the lack of meningioma cell lines and tumor models for preclinical studies. There is significant experience with targeted molecular agents for systemic cancers and malignant gliomas which may be translated into effective strategies for meningiomas. It is hoped that these novel therapies will complement the traditional approaches and lead to more effective treatment for patients with meningiomas.

\section{References}

1. Adjei AA: Farnesyltransferase inhibitors. Cancer Chemother Biol Response Modif 22:123-133, 2005

2. Adjei AA, Hidalgo M: Intracellular signal transduction pathway proteins as targets for cancer therapy. J Clin Oncol 23:53865403, 2005

3. Andersson U, Guo D, Malmer B, Bergenheim AT, Brannstrom T, Hedman $\mathrm{H}$, et al: Epidermal growth factor receptor family (EGFR, ErbB2-4) in gliomas and meningiomas. Acta Neuropathol 108:135-142, 2004

4. Bek EL, McMillen MA: Endothelins are angiogenic. J Cardiovasc Pharmacol (1 Suppl) 36:S135-S139, 2000

5. Bello L, Zhang J, Nikas DC, Strasser JF, Villani RM, Cheresh DA, et al: Alpha(v)beta3 and alpha(v)beta5 integrin expression in meningiomas. Neurosurgery 47:1185-1195, 2000

6. Black PM, Carroll R, Glowacka D, Riley K, Dashner K: Plateletderived growth factor expression and stimulation in human meningiomas. J Neurosurg 81:388-393, 1994

7. Bondy M, Ligon BL: Epidemiology and etiology of intracranial meningiomas: a review. J Neurooncol 29:197-205, 1996

8. Bruns C, Lewis I, Briner U, Meno-Tetang G, Weckbecker G: SOM230: a novel somatostatin peptidomimetic with broad somatotropin release inhibiting factor (SRIF) receptor binding and a unique antisecretory profile. Eur J Endocrinol 146:707-716, 2002

9. Camphausen K, Tofilon PJ: Combining radiation and molecular targeting in cancer therapy. Cancer Biol Ther 3:247-250, 2004

10. Capdeville R, Buchdunger E, Zimmermann J, Matter A: Glivec (STI571, imatinib), a rationally developed, targeted anticancer drug. Nat Rev Drug Discov 1:493-502, 2002

11. Cargioli TG, Ugur HC, Ramakrishna N, Chan J, Black PM, Carroll RS: Establishment of an in vivo meningioma model with human telomerase reverse transcriptase. Neurosurgery 60:750 760, 2007

12. Carroll RS, Black PM, Zhang J, Kirsch M, Percec I, Lau N, et al: Expression and activation of epidermal growth factor receptors in meningiomas. J Neurosurg 87:315-323, 1997

13. Cavalla P, Schiffer D: Neuroendocrine tumors in the brain. Ann Oncol 12 (Suppl 2): S131-134, 2001
14. Chamberlain MC: Adjuvant combined modality therapy for malignant meningiomas. J Neurosurg 84:733-736, 1996

15. Chamberlain MC: Intracerebral meningiomas. Curr Treat Options Neurol 6:297-305, 2004

16. Chamberlain MC, Blumenthal DT: Intracranial meningiomas: diagnosis and treatment. Expert Rev Neurother 4:641-648, 2004

17. Chamberlain MC, Tsao-Wei DD, Groshen S: Salvage chemotherapy with CPT-11 for recurrent meningioma. J Neurooncol 78: 271-276, 2006

18. Chamberlain MC, Tsao-Wei DD, Groshen S: Temozolomide for treatment-resistant recurrent meningioma. Neurology 62:1210 1212,2004

19. Chi AS, Wen PY: Inhibiting kinases in malignant gliomas. Expert Opin Ther Targets 11:473-496, 2007

20. Citrin D, Ménard C, Camphausen K: Combining radiotherapy and angiogenesis inhibitors: clinical trial design. Int J Radiat Oncol Biol Phys 64:15-25, 2006

21. Crombet T, Torres O, Rodríguez V, Menéndez A, Stevenson A, Ramos M, et al: Phase I clinical evaluation of a neutralizing monoclonal antibody against epidermal growth factor receptor in advanced brain tumor patients: preliminary study. Hybridoma 20:131-136, 2001

22. Cully M, You H, Levine AJ, Mak TW: Beyond PTEN mutations: the PI3K pathway as an integrator of multiple inputs during tumorigenesis. Nat Rev Cancer 6:184-192, 2006

23. Cusimano MD: Hydroxyurea for treatment of meningioma. J Neurosurg 88:938-939, 1998

24. D'Ambrosio AL, Bruce JN: Treatment of meningioma: an update. Curr Neurol Neurosci Rep 3:206-214, 2003

25. Demetri GD, von Mehren M, Blanke CD, Van den Abbeele AD, Eisenberg B, Roberts PJ, et al: Efficacy and safety of imatinib mesylate in advanced gastrointestinal stromal tumors. N Engl J Med 347:472-480, 2002

26. DeMonte F, Marmor E, Al-Mefty O: Meningiomas, in Kaye AH, Laws ER Jr (eds): Brain Tumors: An Encyclopedic Approach, ed 2. London: Churchill Livingstone, 2001, pp 719-750

27. Donnini S, Machein MR, Plate KH, Weich HA: Expression and localization of placenta growth factor and PlGF receptors in human meningiomas. J Pathol 189:66-71, 1999

28. Drake WM, Grossman AB, Hutson RK: Effect of treatment with pegvisomant on meningioma growth in vivo. Eur J Endocrinol 152:161-162, 2005

29. Druker BJ, Talpaz M, Resta DJ, Peng B, Buchdunger E, Ford JM, et al: Efficacy and safety of a specific inhibitor of the BCR-ABL tyrosine kinase in chronic myeloid leukemia. N Engl J Med 344: 1031-1037, 2001

30. Drummond KJ, Zhu JJ, Black PM: Meningiomas: updating basic science, management, and outcome. Neurologist 10: 113-130, 2004

31. Dy GK, Adjei AA: Obstacles and opportunities in the clinical development of targeted therapeutics. Prog Drug Res 63:19-41, 2005

32. Engelman JA, Luo J, Cantley LC: The evolution of phosphatidylinositol 3-kinases as regulators of growth and metabolism. Nat Rev Genet 7:606-619, 2006

33. Fisher R, Fadul C, Chamberlain MC: Potential efficacy of somatostatin for treatment of recurrent meningiomas. Neurology 66: A339, 2006

34. Folkman J: Angiogenesis. Annu Rev Med 57:1-18, 2006

35. Friend KE: Cancer and the potential place for growth hormone receptor antagonist therapy. Growth Horm IGF Res 11 (Suppl A):S121-S123, 2001

36. Friend KE, Radinsky R, McCutcheon IE: Growth hormone receptor expression and function in meningiomas: effect of a specific receptor antagonist. J Neurosurg 91:93-99, 1999

37. García-Luna PP, Relimpio F, Pumar A, Pereira JL, Leal-Cerro A, Trujillo F, et al: Clinical use of octreotide in unresectable meningiomas. A report of three cases. J Neurosurg Sci 37:237-241, 1993 
38. Ghobrial IM, Witzig TE, Adjei AA: Targeting apoptosis pathways in cancer therapy. Ca Cancer J Clin 55:178-194, 2005

39. Goldman CK, Bharara S, Palmer CA, Vitek J, Tsai JC, Weiss HL, et al: Brain edema in meningiomas is associated with increased vascular endothelial growth factor expression. Neurosurgery 40: 1269-1277, 1997

40. Goldsmith B, McDermott MW: Meningioma. Neurosurg Clin N Am 17:111-120, 2006

41. Goodwin JW, Crowley J, Eyre HJ, Stafford B, Jaeckle KA, Townsend JJ: A phase II evaluation of tamoxifen in unresectable or refractory meningiomas: a Southwest Oncology Group study. J Neurooncol 15:75-77, 1993

42. Graner MW, Bigner DD: Therapeutic aspects of chaperones/heatshock proteins in neuro-oncology. Expert Rev Anticancer Ther 6:679-695, 2006

43. Grunberg SM: Role of antiprogestational therapy for meningiomas. Hum Reprod 9 (1 Suppl):202-207, 1994

44. Grunberg SM, Rankin C, Townsend J, Ahmadi J, Feun L, Fredericks R, et al: Phase III double-blind randomized placebo-controlled study of mifepristone (RU) for the treatment of unresectable meningioma. Proc Am Soc Clin Oncol 20:222, 2001 (Abstract)

45. Grunberg SM, Weiss MH, Spitz IM, Ahmadi J, Sadun A, Russell CA, et al: Treatment of unresectable meningiomas with the antiprogesterone agent mifepristone. J Neurosurg 74:861-866, 1991

46. Hansson CM, Buckley PG, Grigelioniene G, Piotrowski A, Hellströöm AR, Mantripragada K, et al: Comprehensive genetic and epigenetic analysis of sporadic meningioma for macro-mutations on $22 \mathrm{q}$ and micro-mutations within the NF2 locus. BMC Genomics 8: 16, 2007

47. Harland SP, Kuc RE, Pickard JD, Davenport AP: Expression of endothelin(A) receptors in human gliomas and meningiomas, with high affinity for the selective antagonist PD156707. Neurosurgery 43:890-899, 1998

48. Henze M, Dimitrakopoulou-Strauss A, Milker-Zabel S, Schuhmacher J, Strauss LG, Doll J, et al: Characterization of 68GaDOTA-D-Phe1-tyr3-octreotide kinetics in patients with meningiomas. J Nucl Med 46:763-769, 2005

49. Herscovici Z, Rappaport Z, Sulkes J, Danaila L, Rubin G: Natural history of conservatively treated meningiomas. Neurology 63: 1133-1134, 2004

50. Homsi J, Cubitt C, Daud A: The Src signaling pathway: a potential target in melanoma and other malignancies. Expert Opin Ther Targets 11:91-100, 2007

51. Hsu DW, Efird JT, Hedley-Whyte ET: MIB-1 (Ki-67) index and transforming growth factor-alpha (TGF alpha) immunoreactivity are significant prognostic predictors for meningiomas. Neuropathol Appl Neurobiol 24:441-452, 1998

52. Hsu DW, Efird JT, Hedley-Whyte ET: Progesterone and estrogen receptors in meningiomas: prognostic considerations. J Neurosurg 86:113-120, 1997

53. Jain RK, Duda DG, Clark JW, Loeffler JS: Lessons from phase III clinical trials on anti-VEGF therapy for cancer. Nat Clin Pract Oncol 3:24-40, 2006

54. Johnson M, Toms S: Mitogenic signal transduction pathways in meningiomas: novel targets for meningioma chemotherapy? J Neuropathol Exp Neurol 64:1029-1036, 2005

55. Johnson MD, Horiba M, Winnier AR, Arteaga CL: The epidermal growth factor receptor is associated with phospholipase $\mathrm{C}$-gamma 1 in meningiomas. Hum Pathol 25:146-153, 1994

56. Johnson MD, Okediji E, Woodard A: Transforming growth factor-beta effects on meningioma cell proliferation and signal transduction pathways. J Neurooncol 66:9-16, 2004

57. Johnson MD, Okedli E, Woodard A, Toms SA, Allen GS: Evidence for phosphatidylinositol 3-kinase-Akt-p7S6K pathway activation and transduction of mitogenic signals by platelet-derived growth factor in meningioma cells. J Neurosurg 97:668-675, 2002

58. Johnson MD, Woodard A, Kim P, Frexes-Steed M: Evidence for mitogen-associated protein kinase activation and transduction of mitogenic signals by platelet-derived growth factor in human meningioma cells. J Neurosurg 94:293-300, 2001

59. Jones NR, Rossi ML, Gregoriou M, Hughes JT: Epidermal growth factor receptor expression in 72 meningiomas. Cancer 66: $152-155,1990$

60. Kaba SE, DeMonte F, Bruner JM, Kyritsis AP, Jaeckle KA, Levin $\mathrm{V}$, et al: The treatment of recurrent unresectable and malignant meningiomas with interferon alpha-2B. Neurosurgery 40: 271-275, 1997

61. Kalamarides M, Niwa-Kawakita M, Leblois H, Abramowski V, Perricaudet M, Janin A, et al: Nf2 gene inactivation in arachnoidal cells is rate-limiting for meningioma development in the mouse. Genes Dev 16:1060-1065, 2002

62. Kesari S, Ramakrishna N, Sauvageot C, Stiles CD, Wen PY: Targeted molecular therapy of malignant gliomas. Curr Oncol Rep 8:58-70, 2006

63. Kirsch M, Wilson JC, Black P: Platelet-derived growth factor in human brain tumors. J Neurooncol 35:289-301, 1997

64. Klutmann S, Bohuslavizki KH, Brenner W, Behnke A, Tietje N, Kröger $\mathrm{S}$, et al: Somatostatin receptor scintigraphy in postsurgical follow-up examinations of meningioma. J Nucl Med 39: 1913-1917, 1998

65. Kondraganti S, Gondi CS, Gujrati M, McCutcheon I, Dinh DH, Rao JS, et al: Restoration of tissue factor pathway inhibitor inhibits invasion and tumor growth in vitro and in vivo in a malignant meningioma cell line. Int J Oncol 29:25-32, 2006

66. Kyritsis AP: Chemotherapy for meningiomas. J Neurooncol 29: 269-272, 1996

67. Lamberts SW, Tanghe HL, Avezaat CJ, Braakman R, Wijngaarde R, Koper JW, et al: Mifepristone (RU 486) treatment of meningiomas. J Neurol Neurosurg Psychiatry 55:486-490, 1992

68. Lamszus K: Meningioma pathology, genetics, and biology. J Neuropathol Exp Neurol 63:275-286, 2004

69. Lamszus K, Lengler U, Schmidt NO, Stavrou D, Ergün S, Westphal M: Vascular endothelial growth factor, hepatocyte growth factor/scatter factor, basic fibroblast growth factor, and placenta growth factor in human meningiomas and their relation to angiogenesis and malignancy. Neurosurgery 46:938-948, 2000

70. Lefranc F, Brotchi J, Kiss R: Possible future issues in the treatment of glioblastomas: special emphasis on cell migration and the resistance of migrating glioblastoma cells to apoptosis. J Clin Oncol 23:2411-2422, 2005

71. Letai A, Bassik MC, Walensky LD, Sorcinelli MD, Weiler S, Korsmeyer SJ: Distinct BH3 domains either sensitize or activate mitochondrial apoptosis, serving as prototype cancer therapeutics. Cancer Cell 2:183-192, 2002

72. Linggood RM, Hsu DW, Efird JT, Pardo FS: TGF alpha expression in meningioma-tumor progression and therapeutic response. J Neurooncol 26:45-51, 1995

73. Liu T, Kuljaca S, Tee A, Marshall GM: Histone deacetylase inhibitors: multifunctional anticancer agents. Cancer Treat Rev 32: 157-165, 2006

74. Louis DN, Scheithauer BW, Budka H: Meningeal tumors, in Kleihues P, Cavenee WK (eds): World Health Organization Classification of Tumours. Pathology and Genetics of Tumours of the Nervous System. Lyon: IARC, 2000, pp 175-196

75. Loven D, Hardoff R, Sever ZB, Steinmetz AP, Gornish M, Rappaport $\mathrm{ZH}$, et al: Non-resectable slow-growing meningiomas treated by hydroxyurea. J Neurooncol 67:221-226, 2004

76. Luo Y, Leverson JD: New opportunities in chemosensitization and radiosensitization: modulating the DNA-damage response. Expert Rev Anticancer Ther 5:333-342, 2005

77. Magrassi L, De-Fraja C, Conti L, Butti G, Infuso L, Govoni S, et al: Expression of the JAK and STAT superfamilies in human meningiomas. J Neurosurg 91:440-446, 1999

78. Markwalder TM, Seiler RW, Zava DT: Antiestrogenic therapy of meningiomas - a pilot study. Surg Neurol 24:245-249, 1985

79. Martínez-Rumayor A, Arrieta O, Guevara P, Escobar E, Rembao 
D, Salina C, et al: Coexpression of hepatocyte growth factor/scatter factor $(\mathrm{HGF} / \mathrm{SF})$ and its receptor $\mathrm{cMET}$ predict recurrence of meningiomas. Cancer Lett 213:117-124, 2004

80. Mason WP, Gentili F, Macdonald DR, Hariharan S, Cruz CR, Abrey LE: Stabilization of disease progression by hydroxyurea in patients with recurrent or unresectable meningioma. J Neurosurg 97:341-346, 2002

81. Mawrin C, Sasse T, Kirches E, Kropf S, Schneider T, Grimm C, et al: Different activation of mitogen-activated protein kinase and Akt signaling is associated with aggressive phenotype of human meningiomas. Clin Cancer Res 11:4074-4082, 2005

82. Maxwell M, Galanopoulos T, Hedley-Whyte ET, Black PM, Antoniades $\mathrm{HN}$ : Human meningiomas co-express plateletderived growth factor (PDGF) and PDGF-receptor genes and their protein products. Int J Cancer 46:16-21, 1990

83. McCutcheon IE: The biology of meningiomas. J Neurooncol 29: 207-216, 1996

84. McCutcheon IE, Flyvbjerg A, Hill H, Li J, Bennett WF, Scarlett JA, et al: Antitumor activity of the growth hormone receptor antagonist pegvisomant against human meningiomas in nude mice. J Neurosurg 94:487-492, 2001

85. McCutcheon IE, Friend KE, Gerdes TM, Zhang BM, Wildrick DM, Fuller GN: Intracranial injection of human meningioma cells in athymic mice: an orthotopic model for meningioma growth. $\mathbf{J}$ Neurosurg 92:306-314, 2000

86. McLean GW, Carragher NO, Avizienyte E, Evans J, Brunton VG, Frame MC: The role of focal-adhesion kinase in cancer-a new therapeutic opportunity. Nat Rev Cancer 5:505-515, 2005

87. McMullen KP, Stieber VW: Meningioma: current treatment options and future directions. Curr Treat Options Oncol 5: 499-509, 2004

88. Mocellin S, Rossi CR, Brandes A, Nitti D: Adult soft tissue sarcomas: conventional therapies and molecularly targeted approaches. Cancer Treat Rev 32:9-27, 2006

89. Modha A, Gutin PH: Diagnosis and treatment of atypical and anaplastic meningiomas: a review. Neurosurgery 57:538-550, 2005

90. Muhr C, Gudjonsson O, Lilja A, Hartman M, Zhang ZJ, Långström B: Meningioma treated with interferon-alpha, evaluated with [(11)C]-L-methionine positron emission tomography. Clin Cancer Res 7:2269-2276, 2001

91. Nabors LB, Mikkelsen T, Rosenfeld SS, Hochberg F, Akella NS, Fisher JD, et al: Phase I and correlative biology study of cilengitide in patients with recurrent malignant glioma. J Clin Oncol 25: 1651-1657, 2007

92. Nagashima G, Asai J, Suzuki R, Fujimoto T: Different distribution of c-myc and MIB-1 positive cells in malignant meningiomas with reference to TGFs, PDGF, and PgR expression. Brain Tumor Pathol 18:1-5, 2001

93. Nakada M, Nakada S, Demuth T, Tran NL, Hoelzinger DB, Berens ME: Molecular targets of glioma invasion. Cell Mol Life Sci 64:458-478, 2007

94. Nakanishi C, Toi M: Nuclear factor-kappaB inhibitors as sensitizers to anticancer drugs. Nat Rev Cancer 5:297-309, 2005

95. Newton HB: Molecular neuro-oncology and the development of targeted therapeutic strategies for brain tumors. Part 5: apoptosis and cell cycle. Expert Rev Anticancer Ther 5:355-378, 2005

96. Newton HB, Scott SR, Volpi C: Hydroxyurea chemotherapy for meningiomas: enlarged cohort with extended follow-up. Br J Neurosurg 18:495-499, 2004

97. Nordqvist AC, Mathiesen T: Expression of IGF-II, IGFBP-2, -5, and -6 in meningiomas with different brain invasiveness. J Neurooncol 57:19-26, 2002

98. Nordqvist AC, Peyrard M, Pettersson H, Mathiesen T, Collins VP, Dumanski JP, et al: A high ratio of insulin-like growth factor II/insulin-like growth factor binding protein 2 messenger RNA as a marker for anaplasia in meningiomas. Cancer Res 57: 2611-2614, 1997

99. Nordqvist AC, Smurawa H, Mathiesen T: Expression of matrix metalloproteinases 2 and 9 in meningiomas associated with different degrees of brain invasiveness and edema. J Neurosurg 95:839-844, 2001

100. O'Donnell JL, Joyce MR, Shannon AM, Harmey J, Geraghty J, Bouchier-Hayes D: Oncological implications of hypoxia inducible factor- $1 \alpha$ (HIF-1 $\alpha)$ expression. Cancer Treat Rev 32:407-416, 2006

101. Okamoto H, Li J, Vortmeyer AO, Jaffe H, Lee YS, Glasker S, et al: Comparative proteomic profiles of meningioma subtypes. Cancer Res 66:10199-10204, 2006

102. Oltersdorf T, Elmore SW, Shoemaker AR, Armstrong RC, Augeri DJ, Belli BA, et al: An inhibitor of Bcl-2 family proteins induces regression of solid tumors. Nature 435:677-681, 2005

103. Pagotto U, Arzberger T, Hopfner U, Sauer J, Renner U, Newton CJ, et al: Expression and localization of endothelin-1 and endothelin receptors in human meningiomas. Evidence for a role in tumoral growth. J Clin Invest 96:2017-2025, 1995

104. Perry A, Cai DX, Scheithauer BW, Swanson PE, Lohse CM, Newsham IF, et al: Merlin, DAL-1, and progesterone receptor expression in clinicopathologic subsets of meningioma: a correlative immunohistochemical study of 175 cases. J Neuropathol Exp Neurol 59:872-879, 2000

105. Perry A, Gutmann DH, Reifenberger G: Molecular pathogenesis of meningiomas. J Neurooncol 70:183-202, 2004

106. Pietras K, Sjöblom T, Rubin K, Heldin CH, Ostman A: PDGF receptors as cancer drug targets. Cancer Cell 3:439-443, 2003

107. Piro LD: Apoptosis, Bcl-2 antisense, and cancer therapy. Oncology (Williston Park) 18 (Suppl 10):5-10, 2004

108. Provias J, Claffey K, delAguila L, Lau N, Feldkamp M, Guha A: Meningiomas: role of vascular endothelial growth factor/ vascular permeability factor in angiogenesis and peritumoral edema. Neurosurgery 40:1016-1026, 1997

109. Puduvalli VK, Li JT, Chen L, McCutcheon IE: Induction of apoptosis in primary meningioma cultures by fenretinide. Cancer Res 65:1547-1553, 2005

110. Ragel B, Jensen RL: New approaches for the treatment of refractory meningiomas. Cancer Control 10:148-158, 2003

111. Rao JS: Molecular mechanisms of glioma invasiveness: the role of proteases. Nat Rev Cancer 3:489-501, 2003

112. Reardon DA, Egorin MJ, Quinn JA, Rich JN, Gururangan S, Vredenburgh JJ, et al: Phase II study of imatinib mesylate plus hydroxyurea in adults with recurrent glioblastoma multiforme. J Clin Oncol 23:9359-9368, 2005

113. Reed JC: Apoptosis-targeted therapies for cancer. Cancer Cell 3:17-22, 2003

114. Rosenthal MA, Ashley DL, Cher L: Treatment of high risk or recurrent meningiomas with hydroxyurea. J Clin Neurosci 9: 156-158, 2002

115. Rowinsky EK: Targeted induction of apoptosis in cancer management: the emerging role of tumor necrosis factor-related apoptosis-inducing ligand receptor activating agents. J Clin Oncol 23:9394-9407, 2005

116. Russell JS, Burgan W, Oswald KA, Camphausen K, Tofilon PJ: Enhanced cell killing induced by the combination of radiation and the heat shock protein 90 inhibitor 17-allylamino17-demethoxygeldanamycin: a multitarget approach to radiosensitization. Clin Cancer Res 9:3749-3755, 2003

117. Salhia B, Tran NL, Symons M, Winkles JA, Rutka JT, Berens ME: Molecular pathways triggering glioma cell invasion. Expert Rev Mol Diagn 6:613-626, 2006

118. Sanfilippo JS, Rao CV, Guarnaschelli JJ, Woost PG, Byrd VM, Jones E, et al: Detection of epidermal growth factor and transforming growth factor alpha protein in meningiomas and other tumors of the central nervous system in human beings. Surg Gynecol Obstet 177:488-496, 1993

119. Sanson M, Cornu P: Biology of meningiomas. Acta Neurochir (Wien) 142:493-505, 2000 
120. Schimmer AD, Dalili S: Targeting the IAP family of caspase inhibitors as an emerging therapeutic strategy. Hematology Am Soc Hematol Educ Program:215-219, 2005

121. Schimmer AD, Dalili S, Batey RA, Riedl SJ: Targeting XIAP for the treatment of malignancy. Cell Death Differ 13: 179-188, 2006

122. Schrell UM, Rittig MG, Anders M, Kiesewetter F, Marschalek $\mathrm{R}$, Koch UH, et al: Hydroxyurea for treatment of unresectable and recurrent meningiomas. I. Inhibition of primary human meningioma cells in culture and in meningioma transplants by induction of the apoptotic pathway. J Neurosurg 86:845-852, 1997

123. Schrell UM, Rittig MG, Anders M, Koch UH, Marschalek R, Kiesewetter F, et al: Hydroxyurea for treatment of unresectable and recurrent meningiomas. II. Decrease in the size of meningiomas in patients treated with hydroxyurea. J Neurosurg 86:840-844, 1997

124. Schwartz GK, Shah MA: Targeting the cell cycle: a new approach to cancer therapy. J Clin Oncol 23:9408-9421, 2005

125. Shapiro GI: Cyclin-dependent kinase pathways as targets for cancer treatment. J Clin Oncol 24:1770-1783, 2006

126. Siddique K, Yanamandra N, Gujrati M, Dinh D, Rao JS, Olivero W: Expression of matrix metalloproteinases, their inhibitors, and urokinase plasminogen activator in human meningiomas. Int J Oncol 22:289-294, 2003

127. Todo T, Adams EF, Fahlbusch R, Dingermann T, Werner H: Autocrine growth stimulation of human meningioma cells by platelet-derived growth factor. J Neurosurg 84:852-859, 1996

128. Wang JL, Nistér M, Hermansson M, Westermark B, Pontén J: Expression of PDGF beta-receptors in human meningioma cells. Int J Cancer 46:772-778, 1990

129. Watson MA, Gutmann DH, Peterson K, Chicoine MR, Kleinschmidt-DeMasters BK, Brown HG, et al: Molecular characterization of human meningiomas by gene expression profiling using high-density oligonucleotide microarrays. Am J Pathol 161:665-672, 2002

130. Weisman AS, Raguet SS, Kelly PA: Characterization of the epidermal growth factor receptor in human meningioma. Cancer Res 47:2172-2176, 1987

131. Wen PY, Drappatz J: Novel therapies for meningiomas. Expert Rev Neurother 6:1447-1464, 2006

132. Wen PY, Kesari S, Drappatz J: Malignant gliomas: strategies to increase the effectiveness of targeted molecular treatment. Expert Rev Anticancer Ther 6:733-754, 2006

133. Wen PY, Yung WK, Lamborn KR, Dahia PL, Wang Y, Peng B, et al: Phase I/II study of imatinib mesylate for recurrent malignant gliomas: North American Brain Tumor Consortium Study 99-08. Clin Cancer Res 12:4899-4907, 2006
134. Wen PY, Yung WKA, Lamborn KR, Cloughesy TF, DeAngelis LM, Fine HA, et al: Phase II study of imatinib mesylate (ST1571) for patients with recurrent meningiomas (NABTC 01-08), presented at Society for Neuro-Oncology Annual Meeting, 2006

135. Whittle IR, Smith C, Navoo P, Collie D: Meningiomas. Lancet 363:1535-1543, 2004

136. Winkler F, Kozin SV, Tong RT, Chae SS, Booth MF, Garkavtsev I, et al: Kinetics of vascular normalization by VEGFR2 blockade governs brain tumor response to radiation: role of oxygenation, angiopoietin-1, and matrix metalloproteinases. Cancer Cell 6:553-563, 2004

137. Wolfsberger S, Doostkam S, Boecher-Schwarz HG, Roessler K, van Trotsenburg M, Hainfellner JA, et al: Progesterone-receptor index in meningiomas: correlation with clinico-pathological parameters and review of the literature. Neurosurg $\operatorname{Rev} 27: 238-245,2004$

138. Wrobel G, Roerig P, Kokocinski F, Neben K, Hahn M, Reifenberger G, et al: Microarray-based gene expression profiling of benign, atypical and anaplastic meningiomas identifies novel genes associated with meningioma progression. Int $\mathbf{J}$ Cancer 114:249-256, 2005

139. Yang SY, Xu GM: Expression of PDGF and its receptor as well as their relationship to proliferating activity and apoptosis of meningiomas in human meningiomas. J Clin Neurosci 8 (Suppl 1):49-53, 2001

140. Yazaki T, Takamiya Y, Costello PC, Mineta T, Menon AG, Rabkin SD, et al: Inhibition of angiogenesis and growth of human non-malignant and malignant meningiomas by TNP470. J Neurooncol 23:23-29, 1995

141. Zang KD: Meningioma: a cytogenetic model of a complex benign human tumor, including data on 394 karyotyped cases. Cytogenet Cell Genet 93:207-220, 2001

142. Zeidman LA, Ankenbrandt WJ, Paleologos N, Vick NA: Analysis of growth rate in non-operated meningiomas. Neurology 66: $\mathrm{A} 400,2006$

Manuscript submitted June 12, 2007.

Accepted August 8, 2007.

This work was supported by a grant from the Brain Science Foundation.

Address correspondence to: Patrick Y. Wen, M.D., Center for Neuro-Oncology, Dana-Farber/Brigham and Women's Cancer Center, SW430D, 44 Binney Street, Boston, Massachusetts 02115. email: pwen@partners.org. 